特集「第10回大会」

原著論文

加速度センサのコントローラを用いたゲームの制作および 高校生のインタラクション分析

\author{
増崎 武次*, 馬場 哲晃**, 藤木 淳***, \\ 横尾 誠****, 牛尼 剛聡*****, 富松 潔***** \\ *八女工業高等学校, ** 首都大学東京システムデザイン学部, *** 日本学術振興会特別研究員/九州大学, \\ **** 会津大学短期大学部, ***** 九州大学大学院芸術工学研究院
}

\title{
GAME CREATIONS BY USING A MOTION-SENSITIVE CONTROLLER AND INTERACTION ANALYSIS OF HIGH SCHOOL STUDENTS
}

\author{
Takeji MASUZAKI*, Tetsuaki BABA**, Jun FUJIKI***, \\ Makoto YOKOO****, Taketoshi USHIAMA***** and Kiyoshi TOMIMATSU***** \\ * Yame Technical High School, 301-4 Hainuduka, Chikugo-shi, Fukuoka 833-0003, Japan \\ ** Faculty of System Design, Tokyo Metropolitan University, 6-6 Asahigaoka, Hino-shi, Tokyo, 191-0065, Japan \\ *** JSPS/Kyushu University, 4-9-1 Shiobaru, Minami-ku, Fukuoka-shi, Fukuoka, 815-8540, Japan \\ **** Junior College of Aizu, 1-1 Yahata, Kadota, Ikki-machi, Aizu-Wakamatsu-shi, Fukushima, 965-8570, Japan \\ ***** Faculty of Design, Kyushu University, 4-9-1 Shiobaru, Minami-ku, Fukuoka-shi, Fukuoka, 815-8540, Japan
}

\begin{abstract}
We developed the experiment teaching materials for high school students to learn motion-sensitive controllers, and got a hint to Nintendo's Wii. They are able to game designs and creations by using Wii-like controller. We carried out questionnaire survey about free answer and extracted KANSEI word with morphological analysis. There is more positive word than negative word. So, we confirmed teacher-student, student-student and student-content interaction. We visualized an interaction with a KeyGraph and got knowledge about the transformation of interactions.
\end{abstract}

Keywords : Motion-sensitive controller, Game, Questionary survey, Interaction, Morphological analysis, KeyGraph

\section{1.は じめに}

今日, 開発·市販されているゲームにはコンソールゲーム, モバイルゲーム, オンラインゲーム, アーケードゲームなど エンターテイメント中心のゲームが数多くあるが, 近年はエ ンターテイメントに教育的な要素を織り込んだ「エデュテイ メント」や福祉・医療目的の「リハビリテイメント」の研究 [1] も盛んになりつつある。このようなエンターテイメント以外 の目的・効用をもつゲームは「シリアスゲーム」［2］と呼 ばれている

一方，日本は「ゲーム大国」，「ゲームの聖地」と呼ばれな がらも学術的な研究分野では欧米諸国に遅れをとり，シリア スゲームの認知度も低い。このような要因には開発費の高騰 や国内市場の縮小，海外市場との激戦などがあり，ゲームに 対するネガティブな言説も見逃せない事実である. そのため メガヒット商品の任天堂DS やWii を教育・健康分野に導入 する動きもあるが，旧態依然として保護者や現場の教師には 受け入られない傾向にある。

最近の先行研究によればMagnussen [3] らはゲームを学校 の授業に導入することで, 教師の役割について研究を行って いる. 教師がゲームのルールや新たな教育的な状況, 役割に 適応しない場合は「教師一生徒」間にインタラクションが生 まれず，教育効果が得られないと結論づけている。また
Sanford [4] らはカナダの高校で行われたゲーム開発の授業 について報告しており，生徒たちの観察やインタビュー，ビ デオ録画を通して，教育現場にゲームを導入する教育的価值 と可能性について述べ, Peppler [5] らはエスノグラフィの 観点からゲーム開発の教育効果について研究を行った。さら に七邊 [1, 6] らは詫間高等専門学校にオンラインゲームを導 入することで教育効果の有無を統計学的に検証し, さらには 「生徒-生徒」間のインタラクションについても考察している.

このような背景のもと筆者らはWiiにヒント得て, 図 1 の ような加速度センサのコントローラを開発し，高校の現場に おいてゲーム制作の研究授業 [7］を実践してきた。一般に ゲームの行為そのものはユーザとゲーム機とのインタラク ションであるが，教育現場でゲームをどのような文脈で利用

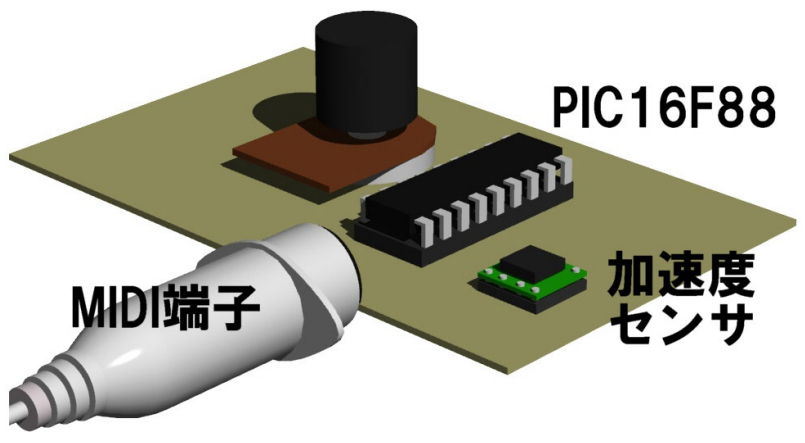

図1 コントローラの構成 
すればよいのか?, またゲームのルールや目的，シナリオを どのようにデザインすればよいのか?,この本質的な「問い」 に対する「答え」は，未だ明確にされていない。このように ゲームの効能を評価するための指標づくりや標準化が急務中 の急務 [1] である.

そこで筆者らはこれらを問題提起とし，ユーザが想起した シナリオ $[8,9]$ に注目した. シナリオとは上記のインタラ クションも含まれるが, 広義的には授業の構成要素 [10] におけるインタラクション，すなわち授業分析もしくは文脈 分析に扔ける教育事象の系列であると考えた。このシナリオ によってユーザは「興味・関心・意欲」を表出させ, 構成要 素の関連性についても獲得する.

本研究の目的はゲームの演習や制作, プレイによって生じ る「教師-生徒」や「生徒-生徒」,「生徒-教材」間のイン タラクションを検証し, それがどのように変容したかを明ら かにすることにある。

\section{2. 加速度センサを用いたコントローラの開発}

\section{1 関 連 研 究}

鈴木 $[11,12]$ らは加速度センサを用いて高校生向けの実 験教材を開発し, 機能的な側面と教育的な側面の双方から教 材を評価している.また栃木県教育センター調査研究部 [13] は,「Wiiリモコン」を利用して加速度を計測する高校生向け の教材を開発している，さらに専門高校では全国工業高等学 校長協会主催の「高校生ものづくりコンテスト」が毎年開催 され，2007 年度の電子回路組立部門 [14］においては加速 度センサも制御対象のひとつとして課題に加えられるように なった。この競技は各県代表の生徒が大会当日に課される問 題に従って電子回路を設計・製作するもので, パソコンを用 いてプログラミングの技術力を競い合うコンテストである.

\section{2 教材開発の仕様}

Wii リモコンは高度なハードウェアとソフトウェアから構 成され, 完全なブラック・ボックスの状態にあることから高 校生には理解しづらい，そこで若者の科学技術離れが叫ばれ る昨今, Wii ライクな実験教材を開発すれば, 学習指導要領 の観点別評価にあるような「興味・関心・意欲」を引き出せ るのではないかと考え, 先行研究の事例に習って教材開発の 仕様を次のように取り決めた.

まずハードについては(1)被験者が高校生であることを考慮 して生徒たちのレディネスが活かせるようコントローラの電子 回路は簡素化する.ソフトについては(2)コントローラを左右に 傾けるとモニタ上のプレイヤも同期して左右に移動し，コント ローラを上に振るとプレイヤも上方向にジャンプできよう移 動用とジャンプ用などのモジュールを開発する. また(3)生徒 たちがゲームの演習やゲーム制作する際の開発環境を考慮し て、モジュールのパラメータには自由度を与える. (4)生徒向 けのデモンストレーションとして「オシロスコープ」を, ゲー ムの演習や制作用として「ジャンピング・ゲーム」を開発する。

\section{3 ハードウェアの構成}

図 2 はコントローラのブロック図で, 加速度センサからパ ソコンまでの信号の流れを表している。 三軸加速度センサの アナログ信号はPIC16F88 の A/D コンバータへ入力され, 変 換されたデジタル信号はMIDI-USBケーブルを介してパソ コンヘと伝達される。

Kionix 社の加速度センサKXM52-1050［15］は図 3 のよ うな構造になっており, 電源電圧 $3.3 \sim 5.0 \mathrm{~V}$, 感度 660 $\mathrm{mV} / \mathrm{g}$, 入力範囲 $\pm 2 \mathrm{~g}$ のスペックである.

さらに図 4 の電子回路について説明すると, $\mathrm{x}$ 軸方向のア ナログ信号はPICのRA0, y 軸はRA1，z軸はRA2へと， いずれも port $\mathrm{A} に$ 接続され，8bitの分解能で $\mathrm{A} / \mathrm{D}$ 変換され る. 変換されたデジタル信号は port BのRB0 とRB2 から MIDI端子を通してパソコンへと送られる。なお VR $10 \mathrm{k} \Omega$ は波形観測の調整用（GNDレベル）のボリュームである.

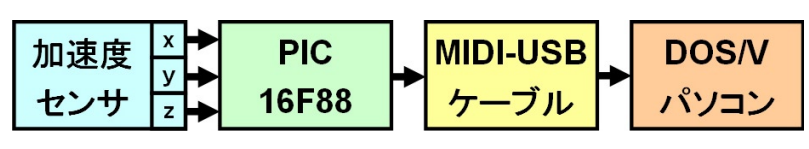

図2 コントローラのブロック図

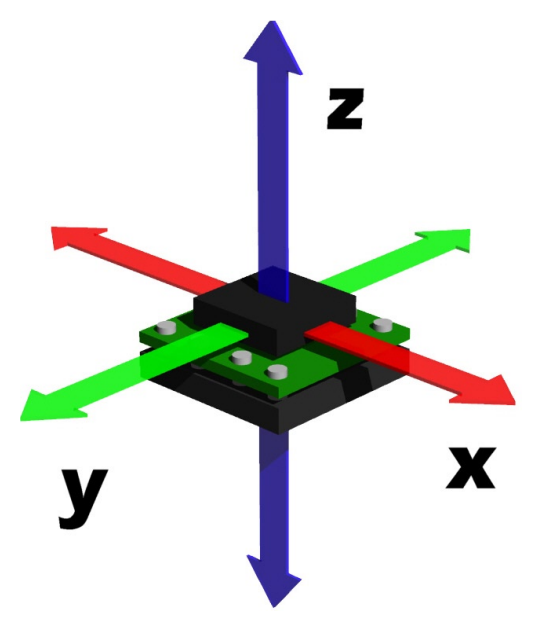

図3 三軸加速度センサ

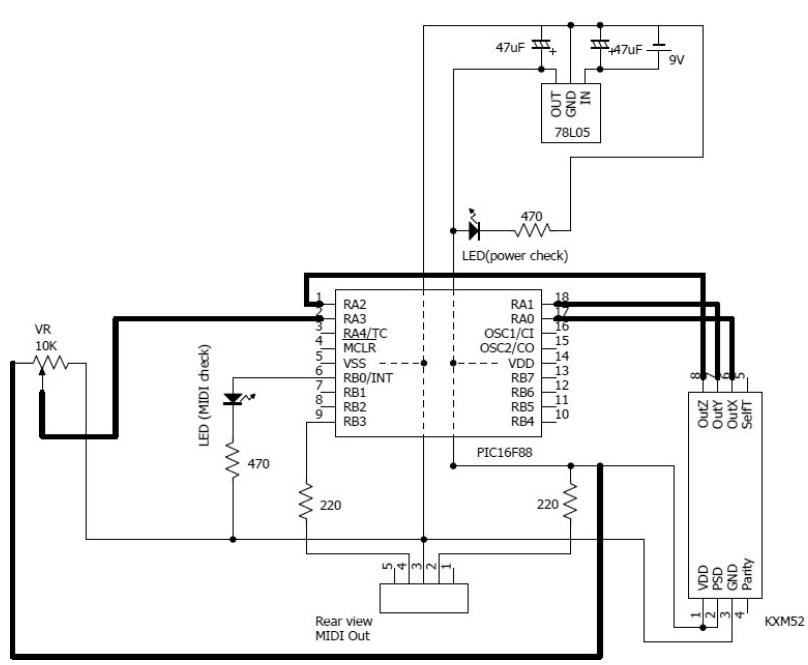

図4 電子回路の構成 


\section{4 オシロスコープの開発}

Microsoft社から無償で提供されている「VisualC++2005 Express Editon」 [16］を用いて, 加速度センサからの出力 をリアルタイムに表示できるよう図 5 のようなオシロスコー プを開発した。 このオシロスコープを用いると，コントロー ラの傾斜状態を時々刻々とモニ夕に表示することができる。

\section{5 ジャンピング・ゲームの開発}

ここでは加速度センサの $\mathrm{x}$ 軸および $\mathrm{z}$ 軸のアナログ信号を 利用して図6のようなジャンピング・ゲームを制作した

ゲームの内容はきわめてシンプルで，プレイヤを画面の左 側から右側へ移動させ，右端に到着できればゲーム・クリア となる。ただし途中でプレイヤがブロックに衝突するとゲー ム・オーバになるので, それを回避するためにプレイヤをジャ ンプさせる必要がある。また生徒がゲームのプログラミング を行う際, 少しでもその負担を軽減できるように種々の関数 をモジュール化した，今回の研究授業では，プレイヤを移動 させる関数player. Draw（）やジャンプさせる関数jump （），ブロックを配置する関数block. Draw（），ブロッ クへの衝突を判定する関数atari（）の4つに限定してゲー ムの演習と制作を行った

\section{3. 研 究 授 業}

\section{1 ヒアリング調査}

研究授業を行う前に現場の意見を伺う目的で, 2007 年 10

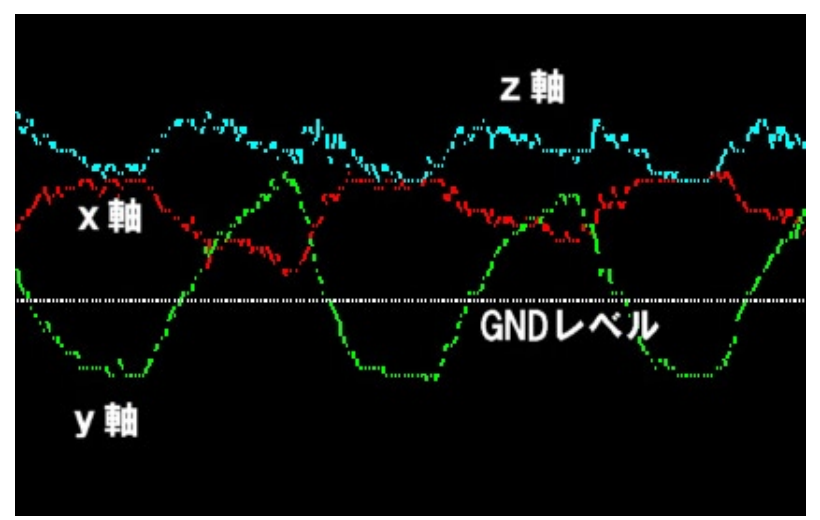

図5＼cjkstart加速度センサを用いたオシロスコープ

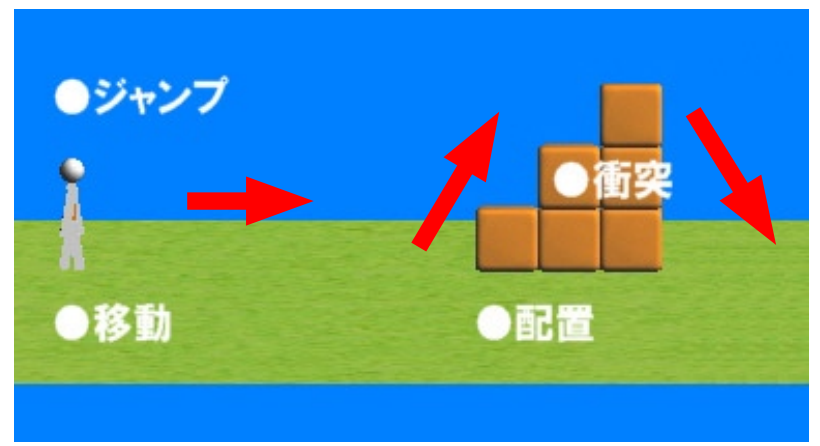

図6 ゲームのルールおよび基本的なモジュール
月 16 日に福岡県立三池工業高等学校 3 年の生徒 2 名を大学 の研究室に招待して、コントローラの評価テストとヒアリン グ調査を行った，研究室では生徒たちにプログラミングの事 例を示しながら同時にゲームの演習も行い，二人一組でゲー ムを制作してもらった。その後のヒアリングよると前述した 四つの仕様はすべて満たされ，生徒たちの違和感は皆無で あった。ささらに当初はマシン 1 台あたり生徒 1 名, 教材 1 台を予定していたが，彼らの意見を採用して研究授業では二 人一組のペア学習で行うことに決定した。

\section{2 被 験 者}

同校電気科 2 年の生徒 38 名 (本来は 40 人学級であるが, 当日の欠席者 1 名, 退学者 1 名）が 1 班 10 名づつに分かれ て，11月７日から 28 日までの毎週水曜日（合計 4 回）に わたって教師 2 名による研究授業が行われた。場所は校内 のCALL教室を利用した.

\section{3 研究授業のカリキュラム}

電気科 2 年生の実習は 3 時限から 6 時限めまでの 4 時間 授業である。シラバス [17] によると電気科の生徒たちは 第 1 回めの実習でLEDの点灯について学習し, 2 回めはス イッチによる入力回路, 3 回めは 7 セグメントのLED表示 回路, 4 回めはLEDデイスプレイ回路, 5 回めはステッピン グ・モー夕，6回めは音入力回路について学習する。このよ うに同校ではコンピュータ制御の基本を学べるようにカリ キュラムが組み込まれ, 今回は第 4 回めの実習内容を加速 度センサの教材と差し替えて行われた。

図 7 は研究授業の様子を撮影したものである。モニ夕の 前面に位置する基板がコントローラで，大きさは手のひら半 分 $(72 \times 47 \mathrm{~mm})$ である. 生徒たちは基板に装着された MIDI端子(MIDIケーブルを介してパソコンのUSB と接続) を把持することで，上下左右に振ることができる，実験教材 は二人一組あたり 1 台としたので，合計 5 台を使用した。

ここでは表 1 に従って研究授業の詳細について述べるこ とにする。最初の 3 時間めはPowerPointを利用しながら, コントローラの歴史について解説した。 また米国で放映され

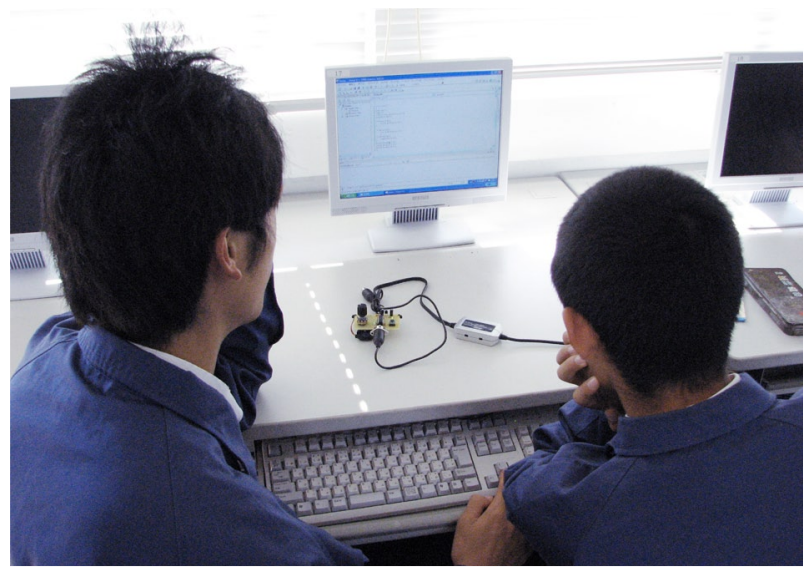

図7 研究授業の様子 
ているWiiのコマーシャルを見せるなどして, 生徒たちの興 味・関心・意欲を触発した。

またWii はユーザの複雑な動きを検出することも可能であ るが, 高校生がそのアルゴリズムを理解することは容易では ない，そこでユーザの動きを三軸方向に特化した剣道に注目 した。

図 8 の A は竹刀を $\mathrm{z}$ 軸方向の上から下へ移動させる「面」 の動きを, また B は竹刀を $\mathrm{y}$ 軸方向の左から右への移動させ る「胴」の動きを表している。いずれの動きも厳密には竹刀 の回転運動であるが, 生徒たちには直線運動と見立てて一連 の動作を解説した.

次に図 5 で示したオシロスコープのデモを行い, 教師が 剣道の面と胴の動作に加えて $\mathrm{x}$ 軸方向の「突き」を実演する ことで, 波形がリアルタイムに変化する様子を生徒たちに示 した。 今度は生徒の理解度を確かめる目的で, ホワイト・ボー ドに身を隠して波形のみを提示して回答させた。このように クイズ形式の授業を行うことで生徒たちの興味・関心・意欲 を引き出した，残りの時間はヒアリング調査で制作してくれ た先輩たちの作品を生徒自身がプレイすることで，コント ローラの操作に慣れ親しんでもらった。

表1 研究授業のカリキュラム

\begin{tabular}{|c|l|}
\hline 時間め & \multicolumn{1}{c|}{ 実習の内容 } \\
\hline 3 & $\begin{array}{l}\cdot \text { PowerPoint を用いて実習の概要を説明 } \\
\cdot \text { オシロスコープによるデモ } \\
\cdot \text { ゲームのデモ }\end{array}$ \\
\hline 4 & $\cdot$ ゲームの演習 \\
\hline 5 & $\begin{array}{l}\cdot \text { ゲームのデザイン } \\
\cdot \text { 話し合い } \\
\text { ゲームの制作 }\end{array}$ \\
\hline 6 & $\begin{array}{l}\cdot \text { ゲームの制作 } \\
\cdot \text { ゲームのプレイ } \\
\cdot \text { アンケートの調査 }\end{array}$ \\
\hline
\end{tabular}

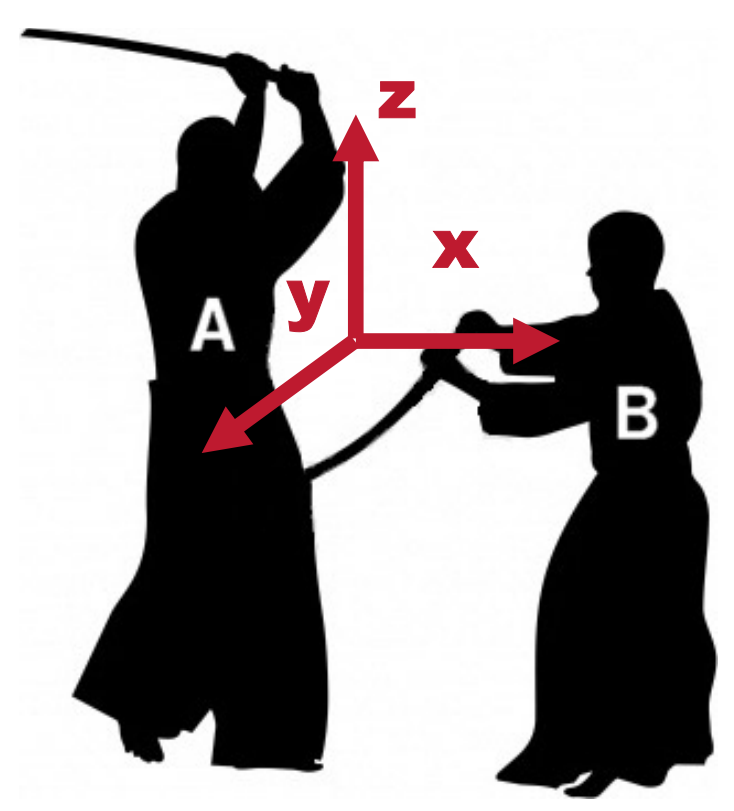

図8 剣道の「面」と「胴」
4 時間めはプログラミングに必要な四つのモジュールにつ いて解説し，その後に同演習を行った。図 9 はプレイヤ移 動のアルゴリズムであり， パラメータ「0.01」はプレイヤの 移動速度, パラメータ「-5」と「+5」はプレイヤの傾斜反 応を決める数值である.

5 時間めの途中まで演習を行い, 後半はこれまで学習した 内容をフルに活用して, ジャンピング・ゲームを制作する.ゲー ムの制作では各自がアイデアをスケッチし, 今度は二人一組 になってどのようなギミック（策略や仕掛け）をゲームに導 入するかを話し合ったあと，プログラミングを開始する.

6 時間めはゲームのプレイを行った. 生徒たちは他の作品 をプレイすることで自分にはない仕掛けを見いだし，また ゲームの難しさに驚き，拈いに楽しんでいる様子であっ た。後半は自由記述方式によるアンケート調査を実施した。

\section{4 アンケート調査}

アンケート調査の書式は図 10 のように「本日の実習で印 象に残ったところや，実習に関する感想，意見，要望などに ついて，自由に記入して下さい」とした。 なお同図には 3 時 間のみ提示しているが, 残りの $4,5,6$ 時間めも同じ書式 である，今回，自由記述方式を採用した理由は，ゲームの演 習や制作など, 毎時間ごとの学習過程を振り返ることで生徒 自身の「リフレクション」や「気づき」に関する知見を得る ことにある．さらに筆者らがこれまで採用してきた 5 件法 [18］によるアンケート調査では生徒たちの本質を知ること は困難だと考え, 今回の研究授業で導入した二人一組の協調 的な学習を通して生徒たちは何を考え?, どのように解決し たのか?，など生徒たちの本音を探りたいと考えた。

今回のアンケート調査はあくまで授業に関する自由記述の 内容であり, そのシナリオがインタラクションのみを表して いるとは限らない.また研究授業で得られたデー夕は生徒た ちからのメッセージであるが,「感性情報」と「知識情報」 が交錯していると考えられる。そこで授業の構成要素である 教師や生徒, 教材のインタラクションを抽出するッールとし て, 次に説明する形態素解析とキーグラフを利用した。

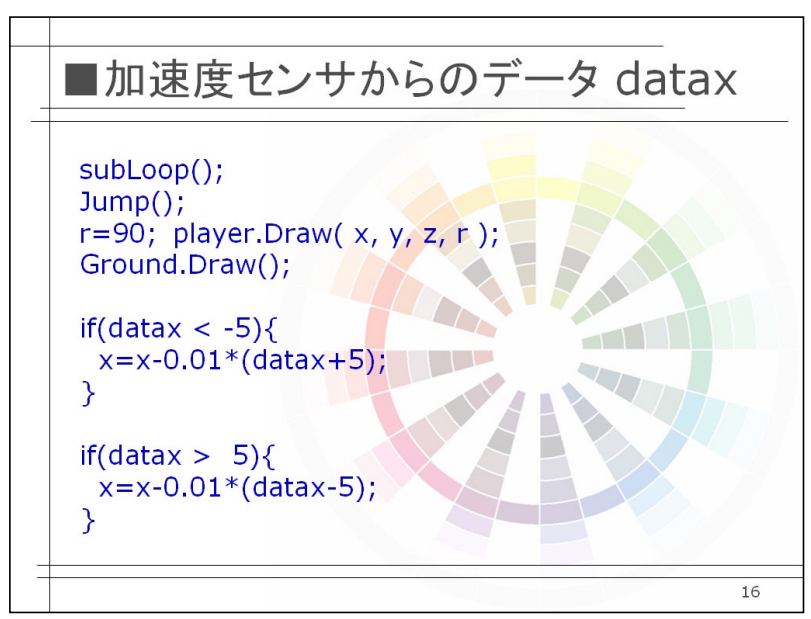

図9 プレイヤ移動のアルゴリズム 


\section{4. インタラクションの検証}

\section{1 形態素解析による感性語の抽出}

インタラクションには「会話」「文字」などの言語的なイ ンタラクションのほかに「振る」，「まわす」といった意識的 な動作や無意識な動作など, 非言語的なインタラクションも 含まれるが，これは「感性」と呼ばれる水山の一角が水面上 に明示化 [19] されたに過ざない。 より密接なインタラクショ ンを具現化するには水面下の実体をつかみ, 何らかの形によっ て表現する必要がある，そこで形態素解析による感性語の頻 度をもって感性情報を含むインタラクションの指標とした。

形態素分析には，2007 年 10 月より無料提供をはじめた ネットマイル社の「TextExplorer」[20]を利用した。このッー ルの特徵は単語ランキングや共起分析, ポジティブ・ネガティ ブの解析などができることである。感性語を抽出する手順と しては，まず(1)アンケート調査の記述内容をテキスト化し て, (2)形態素解析のあと, (3)ノイズ (不要語) の除去を行っ た。あらかじめ分析対象の品詞を形容詞・動詞・名詞・未知 語に設定して，その後「だけ」「「しい」，「そして」のよう な助詞・助動詞・接続詞など，単独では記述内容を特徵づけ ないものを不要語 $[21,22]$ として除去した。また感性語に ついては「すごい」,「分かる」，「良い」といったポジティブ な情動［23］を表す言葉を，またネガティブな情動は「く やしい」,「難しい」,「分からない」などを抽出して，それら の頻度を調べた。

分析の結果, 表 2 のようなポジティブ・ネガティブな感 性語の頻度を得ることができた。 3 時間めから 6 時間めの研 究授業において，いずれの時間帯もネガティブよりもポジ ティブな感性語の頻度が多いことが分かる，またすべての時 間帯の頻度について累計するとポジティブな感性語の総数は 106, ネガティブな感性語が 61 であるから，全体を占める

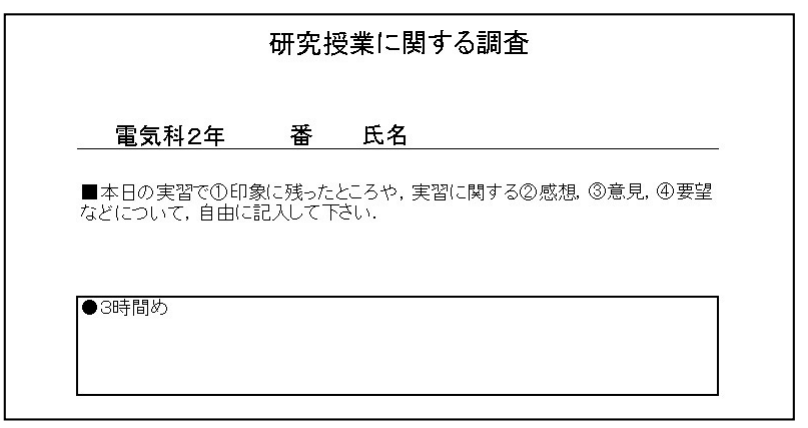

図 10 アンケート調査の書式

表2ポジティブ・ネガティブな感性語の頻度

\begin{tabular}{|c|c|c|}
\hline \multirow{2}{*}{ 時間め } & \multicolumn{2}{|c|}{ 感性語の頻度 } \\
\cline { 2 - 3 } & ポジティブ & ネガティブ \\
\hline 3 & 33 & 17 \\
\hline 4 & 26 & 15 \\
\hline 5 & 23 & 16 \\
\hline 6 & 24 & 13 \\
\hline
\end{tabular}

割合はそれぞれ $63.5 \%$ と $36.5 \%$ となる。

図 11 は時系列的に表現したインタラクションである。こ れは横軸に研究授業の時限を, 縦軸にネガティブとポジティ ブの総数を $100 \%$ に規格化したものであり，青い部分がネガ ティブ, 赤はポジティブな感性語を表している.

以上によりネガティブよりもポジティブな感性語の頻度が 多いことから,「教師-生徒」や「生徒-生徒」,「生徒-教材」 間において，ポジティブなインタラクションが生じたと考え られる。

\section{2 キーグラフによるインタラクションの変容}

分析には大澤 [24]らが開発した「紙芝居キーグラフ」[25] を用いる.キーグラフそのものは文章全体における単語(ノー ド）の共起関係が，その文章の主張する筋道とみなして基礎 概念から導かれる単語をキーワードで抽出する方法であり, 単語の結びつきをマップ上に可視化するッールである。

換言 [26］すれば単語の出現頻度とそれらの共起度から なる語を抽出し, 土台と文章中の各単語の共起度を計算し, その值の大きなものがキーワードとなる，マップ上には高頻 度単語を表す「黒ノード」と低頻度ながらクラス夕（島）と のつながりの深い単語を表す「赤ノード」が表示される。こ の赤ノードに注目することで, 潜在的なニーズを掘り起こ し，新たな知見を見出すことができると言われている。この ようにキーグラフはキーワードを文脈として捉えることがで きるため,「チャンス発見」［27］とシナリオ創出のツール として，ビジネスの分野では幅広く応用されている.

紙芝居キーグラフは従来のキーグラフの機能に時系列的な 表示に特化したツールであり，時間経過の前後において同じ 単語が出現する場合は，ノードの位置が固定されるので, リ ンクとノードの関係を俯瞰することができる。またこのツー

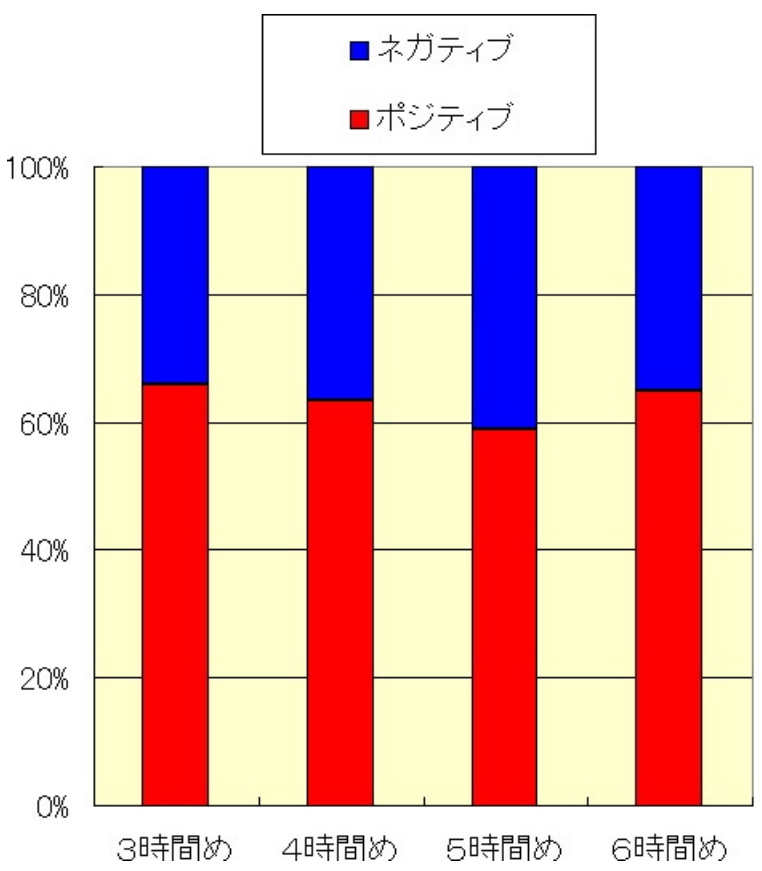

図11 ポジティブ・ネガティブな感性語の頻度 
ルには形態素解析の「茶鉒」［28］が組み込まれており，ノ イズの除去についてはTextExplorerと同じ要領で作業を行っ た．その後，ノードやリンクをパラメータにしながら，大き な構造変化となる特異点を種々の試行錯誤の中から見つけだ した，なお共起度の計算については, log Jaccardを用いた。

この Jaccard係数 [24] は

$$
\operatorname{Jaccard}(a, b)=\frac{p(a \cap b)}{p(a \cup b)}
$$

として表現され, 分子は $a, b$ いずれも含む共起単位の数であ り, 分母は $a, b$ のいずれかを含む共起単位の数である.この 係数はチャンス発見において，よく利用される指標である.

図 12 は紙芝居キーグラフを用いて時間帯ごとに分析した 結果である. 前述したように黒ノードは高頻度の単語, 赤ノー ドは低頻度を表しているが, 形態素分析の結果と照合するこ とで赤ノードは中頻度であることが確認できた．

3 時間めのキーグラフについて解釈してみると, 生徒たち はWiiのコマーシャルに感化されたことが窅える，ちなみポ ジティブな感性語は黒ノードの「できる」と赤ノードの「分 かる」の二つであった

4 時間めになると単語の構造が大きく変化していることが 分かる，黒ノードの「できる」と「思う」が残り, 他はすべ て新たな単語に置き換わった。これらの単語を結合させて, ひとつの文脈として解釈すると「ゲーム制作のプログラム (プ ログラミング）は簡単であった」ことが窥える．研究授業の 最終日, オブザーバとして参加していた現場の先生から「生
徒たちはプログラミングを理解しながらゲームを制作してい るのでしょうか?」と疑問視する声があったが, 分析の結果, 杞憂に過ぎないことが明らかになった。

5 時間めになると劇的に変化し，「ゲーム」や「制作」,「作 る」,「できる」といった四つの黒ノードから構成され，これ までの赤ノードはすべて消失している，ちなみにこの時間は ゲームのデザイン, 二人一組による話し合いの後, ゲームの 制作を実施した。

6 時間めは新たに「思う」と「良い」の二つの黒ノードが 出現し,「時間」や「工夫」,「すごい」,「楽しむ」,「みんな」, 「ある」といった六つの赤ノードが現れ，それぞれ黒ノード の「制作」と「ゲーム」とリンクしている。 その一方で 5 時 間めにおいて「制作-作る」と「制作-できる」の間で結合 していた黒リンクは，6時間めになるとリンクが消失するこ とが確認できる．ポジティブな感性語の頻度については黒 ノードが二つ, 赤ノードは四つであった

今度は 5 時間めと 6 時間めの構造変化に注目する。紙芝 居キーグラフの機能を利用して 5 時間めの黒ノードを固定さ せると, 図 13 のようにインタラクションの変容を一望する ことができる． 6 時間めは 5 時間めに引き続きゲームの制作 を行い, その後，お互いに自分たちのゲームをプレイしあう ことで, CALL教室がもっとも盛り上がった時間帯である.

このように黒ノードと赤ノードの文脈からも理解できるよ うに生徒同士のインタラクションがキーグラフの構造として 如実に表現されている. 以上のように紙芝居キーグラフを利 用することで，新たな知見を得ることができた。
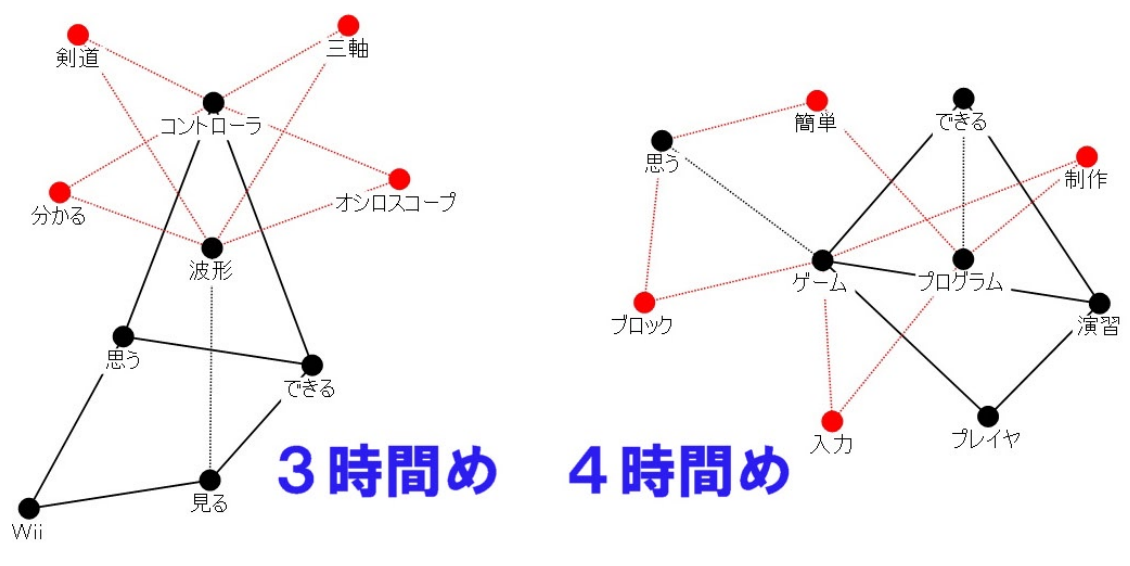

5 時間め 6 時間め
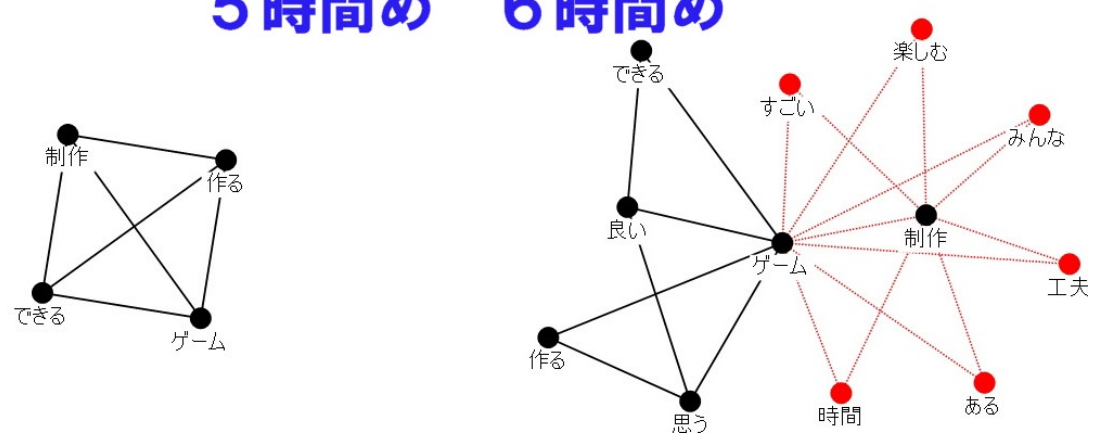

図12 インタラクションの変容（3～6時間め) 


\section{3 関連研究による比較検討}

赤堀 [29］はコンピュータ教材の利用形態について「教 師-子供」や「子供-教材」,「教師-教材-子供」さらに「子 供-子供」の四つに分類している。 またAnderson [30］ら は遠隔教育のインタラクションについて「学習者-学習者」, 「学習者-教授者」「教授者-教授者」,「教授者-教材」,「教 材一教材」,「教材一学習者」の六つに分類している.

筆者らは授業の構成要素に習ってインタラクションの形態 を図 14 のように(1)「教師-生徒」や(2)「生徒-教材」, (3)「生 徒-生徒」間の三つに簡略化した.

これを表 1 のカリキュラムに対応させると表 3 のように なる. 3 時間めから 4 時間めについては抄もに教師主導型の 授業，すなわち教師が中心になって教材の醍䤀味を生徒たち に教えていたが，それ以降は興味・関心・意欲を触発するこ とを第一義に，筆者らはファシリテータ（黒子役）に徹し， 種々の仕掛けを生徒たちに投げかけながら生徒たちの反応を つぶさに観察した

\section{5 時間め}
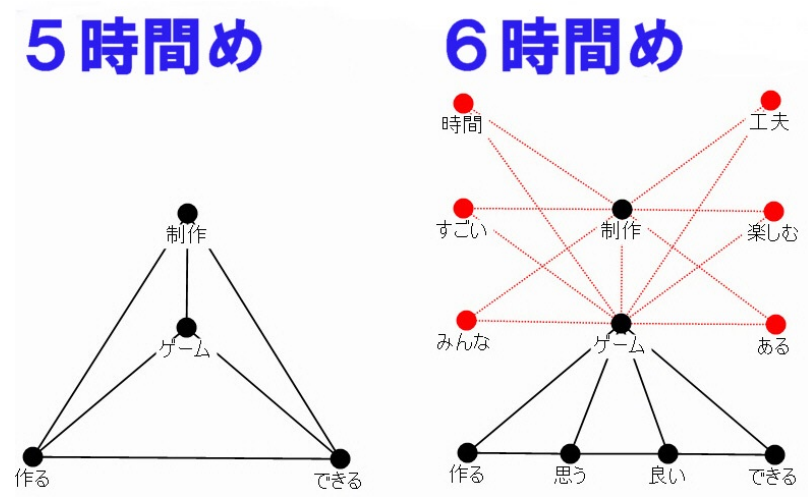

図13 インタラクションの変容（5～6時間め)

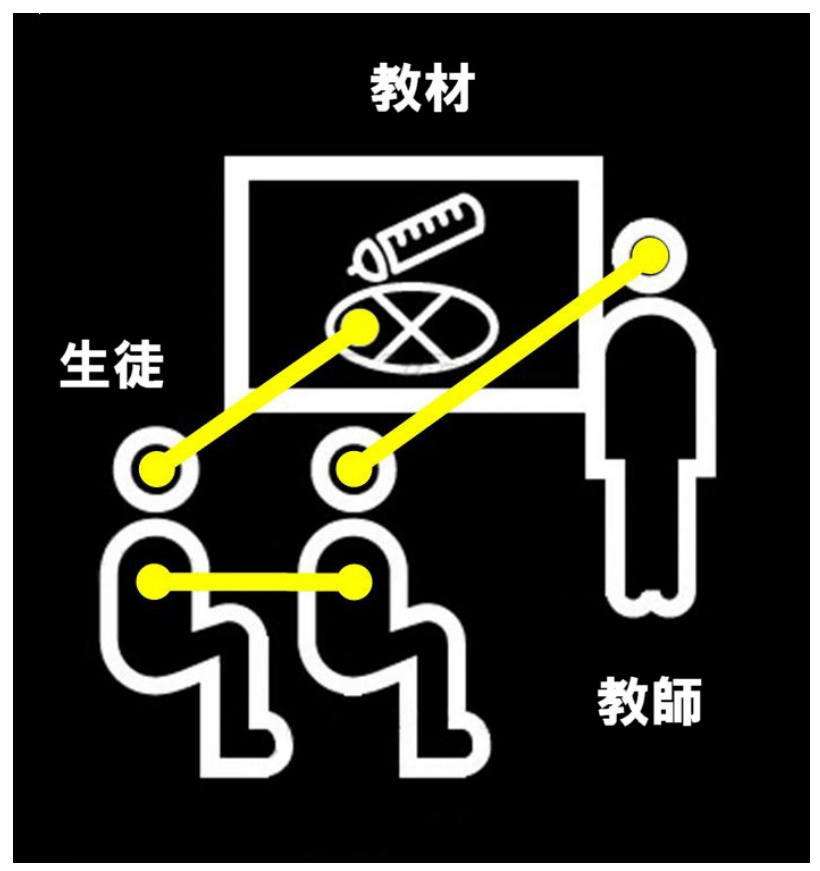

図14 インタラクションの形態 表3＼cjkstart研究授業のカリキュラム

\begin{tabular}{|c|c|c|}
\hline 時間め & 実習の内容 & インタラクションの形態 \\
\hline 3 & $\begin{array}{l}\cdot \text { PowerPoint を用いて実習の } \\
\text { 概要を説明 } \\
\text { · オシロスコープによるデモ } \\
\text { ·ゲームのデモ }\end{array}$ & $\begin{array}{l}\text { (1) } \\
\text { (1) (2) } \\
\text { (1) (2) }\end{array}$ \\
\hline 4 & ·ゲームの演習 & (1) (2) (3) \\
\hline 5 & $\begin{array}{l}\cdot \text { ·ゲームのデザイン } \\
\cdot \text { ·話し合い } \\
\text { ·ゲーム制作 }\end{array}$ & $\begin{array}{l}\text { (3) } \\
\text { (2) (3) }\end{array}$ \\
\hline 6 & $\begin{array}{l}\cdot \text { ゲームの制作 } \\
\cdot \text { ゲームのフプ } \\
\cdot \text { ケンンケートの調査 }\end{array}$ & $\begin{array}{l}\text { (2) (3) } \\
\text { (2) (3) } \\
\text { (1) (2) (3) }\end{array}$ \\
\hline
\end{tabular}

前述した七邊 [1]の研究報告によると「量的なコミュニケー ションを増大させるだけでは, 歴史学習への意欲や社会的ス キルの向上には充分ではないことが明らかになった，教室内 のコミュニケーションは確かに活発であったが, それは教科 内容に関わるものではなく,ゲームのプレイ方法や雑談であっ た。こうした場合，少なくとも短期間では，教科への学習意 欲や歴史知識の獲得とは結びつかないようである. (中略)ゲー ムの面白さが教育効果に影響する」と結論づけている.

それに対し 6 時間めのアンケート調査によると, 生徒たちは

○いろんな班が制作したゲームをして，とても楽しかった。 各班とても工夫していて，中にはビックリするようなト ラップがあり, 良かったと思いました.

○ 5 時間めに考えたアイデアを活かして, ダミーのブロック を配置することで，いろいろな応用ができて良かった．み んなのゲームをやってみて, よく工夫していると思った. 今日の実習は本当に楽しくできました.

○ 完成したコースにちょっとした工夫を加え, さらにおもし ろさを増して，人をワクワクさせるコースを制作すること で，みんなに楽しんでもらった，もう一度，コ一スを作る ときは, プログラムを理解したので, 長めのコースを作っ てみたい.

○ 何かとトラブルを解決しながら, オリジナルのゲームを作 りはじめた. ジャンプするゲームでありながら，下方向へ 沈んでしまうという逆転の発想をゲームに導入した. また 先輩たちのプログラムを参考にしながら、ブロックを動か すことにも成功した. さらにブロックの移動速度を变え て, ゲームのクリアを難しくするなど, 何かと楽しんでや れた. 次回は1日かけてRPGを作ってみたい.

○ 自分の好きなようにゲームを作ることができて，とても楽 しくやれました. ゲームをもっと作ってみたいと思いま す．またゲームを作る機会があれば良いと思います．自宅 でゲームをやるときは, どのようなプログラムで構成され ているのか考えながらプレイすると, これまでにないゲー ムの楽しみがあると思います

とコメントしており，二人一組による協調的な学習がゲーム の制作やプレイを通して「生徒-生徒」と「生徒-教材」間 のインタラクションとなり，その結果が興味・関心・意欲に 結びついたと考えられる。

前述したようにキーグラフを応用した事例は枚挙に遑がな いが，教育の現場にキーグラフを利用した研究事例はこれま であまり存在しなかった，大澤 [31］は，モノづくりの関 係者（実業家と学生）による交流会を開催し，その前後にお 
ける印象の変化をキーグラフによって分析している. 報告書 によると, 学生の関心事である「自分たちの知識が将来の仕 事に役立つかどうか?」が潜在し, 交流会はこの関心に刺激 を与える効果があったと結論づけている。また同氏 [32] は近年, キーグラフを利用した「イノベーションゲーム」と 「アナログゲーム」を開発して, 受講者たちの「感性」と「気 づき」を高めている.

このように教育の現場にキーグラフを導入することはチャ ンス発見あるいは新たな知見へとつながることから，すこぶ る重要であることが窥える。

\section{5.おわりに}

本稿では自由記述形式のアンケート調查に形態素解析と キーグラフを導入して,「教師-生徒」と「生徒-生徒」,「生 徒一教材」間のインタラクション分析を行うことで, ポジティ ブなインタラクションとその変容が確認された. しかし今回 は試行錯誤を繰り返しながらノードやリンクのパラメータを チューニングしたので，インタラクションの分析に主観的な 要素を残したことも見逃せない事実である.

これについて大澤 [33］は「KeyGraphでは，このような 操作によって結果が大きく変化することがある。 この現象を “恣意的に結果を替えることができてしまう”として同ッー ルを低く評価する人も研究者には多い.このような出力の可 変性は従来の解析においてはツールの信頼性を下げるとされ ることもある。しかしチャンス発見においては望ましい性質 である」とコメントしている.

よって今後のインタラクションの分析については, 学習者 および実験教材のインカム・アウトカムも視野に入れ，ツー ル自身がパラメータをチューニングしながら両モデルの「目 的関数」を最小にするような「最適化キーグラフ」の開発も 必要となるであろう。また近い将来, 生徒一人ひとりのシナ リオを数多く分析することで, 学習プロセスおよび学習意欲 の構造変化が数種類のパターンに分類され, その新たな知見 から「教育的瞬間」の一助となることも想像に難くない.

\section{謝 辞}

2007 年度の研究授業において, 4 週間にわたり実習の受 け入れを承諾して下さった福岡県立三池工業高等学校の中川 校長先生（現在は福島高等学校に移動）および電気科主任の 正木先生に感謝の意を表する。なお本研究の一部は, 上月ス ポーツ・教育財団の助成金によるものである.

\section{参考文 献}

［1］社団法人日本機会工業連合会：シリアスゲームの現状調査 報告書, 2008

http://www.dcaj.org/report/2007/ix2_2.html

[2] 藤本徹：シリアスゲーム, 東京電機出版局, pp.3-5, 2007
[3] Rikke Magnussen: Teacher roles in learning games - When games become situated in schools, DiGRA2007 proceedings, pp.610-615, 2007

[4] Sanford Kathy, Madill Leanna:Recognizing New Literacies: Teachers and Students Negotiating the Creation of Video Games in School, DiGRA2007 proceedings, pp.583-589, 2007

[5] Peppler Kylier A., Kafai Yasmin B.: What Videogame Making Can Teach Us About Literacy and Learning: Alternative Pathways into Participatory Culture, DiGRA2007 proceedings, pp.369-376, 2007

［6］七邊信重, 馬場章：オンラインゲームの教育効果 - 歴史 授業に㧍ける『大航海時代 Online』を用いた実証実験, エンタテインメントコンピューティング 2006, 情報処理 学会, pp.157-158, 2006

[7] 増崎武次, 馬場哲晃, 藤木淳, 横尾誠, 牛尼剛聡, 富松潔: 加速度センサを用いたゲーム・コントローラの制作, 日本 産業技術教育学会第2 3 回情報分科会研究発表会, pp.88-92, 2008 http://kyushu-u.ktkr.net/study.html\#08

［8］丹生有紀, 大澤幸生, 西尾チッ゙ル, 中村洋 : 美術鑑賞にお ける人の気づき獲得モデル, 日本行動計量学会大会発表論 文抄録集，Vol.33，pp.32-33，2005

[9］大澤幸生：シナリオ理解を伴うチャンス発見プロセスに関 する研究, 21 世紀COE プログラム 情報科学技術戦略コア 平成 16 年度報告書 第 3 部 大域ディペンダブル情報基盤プ ロジェクト報告, 2004

http://www.i.u-tokyo.ac.jp/coe/report/H16/21COE-ISTSC-H16_3_2_8.pdf

[10］工藤紀篤：インターネットを用いたリアルタイム遠隔授業に おけるインタラクションの実現, 慶応大学卒業論文, 2003 https://www.sfc.wide.ad.jp/thesis/2003/bachelor/kudo.pdf

[11] 鈴木成, 木村捨雄：モノシリック加速度センサを用いた生 徒実験用加速度計の開発研究, 日本科学教育学会,

Vol.11, No.7, pp.49-54, 1997

[12] 木村捨雄, 鈴木成 et al. : 授業開発の研究, 第4章「加速感」 から加速度へと導く新しい力学授業展開, 筑波出版会, 2001

[13] 栃木県教育センター 調査研究部: 高等学校における教科 指導の充実理科《物理領域》学ぶ手応えを実感できる授業 を目指して〔速度・加速度〕, 2008

http://www.tochigi-edu.ed.jp/center/cyosa/cyosakenkyu/ kyokasido_h19/butsuri_all.pdf

[14] 全国工業高等学校長協会 : 第 8 回高校生ものづくりコンテ ス卜全国大会課題電子回路組立部門，2007

http://www.zenkoukyo.or.jp/mono/2007/denshi_kadai.pdf

[15] Kionix, Inc.: Using the Kionix KXM52-1050 Tri-Axis Accelerometer for Hard Drive Shock Protection, 2004 http://www.kionix.com/App-Notes/AN007\%20HDD\%20S hock\%20Protection.htm

[16] Microsoft Corporation: VisualC++2005 Express Editon., 2005 
http://www.microsoft.com/japan/msdn/vstudio/express/past/2005/

[17] 福岡県立三池工業高等学校: 電気科 2 年実習シラバス, 2007 http://miike-tech.fku.ed.jp/sirabasu/el_jishuu.pdf

[18］増崎武次：LED ディスプレイを用いた電脳キャラクタの デザインおよび高校生の感性教育, 2007

http://www.spss.co.jp/labo/survey_paper/papers/2007/ 2007-pd/07-001-1.pdf

[19] 藤本武司, 砂山渡, 山口智浩, 谷内田正彦: 視線情報の可 視化・共有による感性インタラクション支援, 情報処理学 会研究報告, Vol.2003, No.88, pp.119-126, 2003

[20] ネットマイル:テキストマイニングソフト『TextExplorer』 の無料提供を開始!, 2007

http://www.team-lab.com/media/071030textexplorer.pdf

[21]柴田好章：授業分析における量的手法と質的手法の統合に 関する研究, 風間書房, pp.43-46, 2002

[22］古澤照幸：スリル構造についての考察, 埼玉学園大学紀要 人間学部篇, Vol.4, pp.25-34, 2004

[23] 椎塚久雄: 感性工学における感性価值創造の位置づけ, 感 性工学研究論文集,Vol.7, No.3, pp.430-434, 2008

[24] 大澤幸生 : チャンス発見のデータ分析 モデル化 + 可視化 + コミュニケーションーシナリオ創発, 東京電機大学, 2006

[25］伊藤貴一, 大澤幸生：紙芝居キーグラフ，2006 http://web.sfc.keio.ac.jp/"kiichi/kamisibaiwiki/

［26］竹内淑恵, 西尾チヅル：有機野菜に対する消費者の価值構 造一定量分析と定性分析の適用, イノベーション・マネジ メント, No.4, pp.61-77, 2007

[27] 庄司裕子: キーワード【分野】人口知能・マーケティングチャ ンス発見, 感性工学研究論文集, Vol.7, No.4, p.596, 2008

[28] 奈良先端科学技術大学院大学 情報科学研究科 自然言語処 理学講座 松本研究室: ChaSen - 形態素解析器, 2007 http://chasen-legacy.sourceforge.jp/

[29] 佐藤隆博, 赤堀㑆司, 倉田政彦: 教育情報工学の応用, コ ロナ社, pp.67-71, 1991

[30] Terry Anderson, Fathi Elloumi: Theory and Practice of Online Learning, pp.33-60, 2004 http://cde.athabascau.ca/online_book/

[31] 大澤幸生, 高橋武秀, 前川知英, 前田雄佐, 斉藤雄司 : 実 業家と学生の交流会前後に扮ける学生側の変化分析もの づくり基盤産業の再活性化プロジェクトから, 情報処理学 会研究報告 情報システムと社会環境研究報告, Vol.2006, No.114, pp.7-14, 2006

[32］大澤幸生：ゲームを通じてチャンス発見のスキルを鍛えよう http://mag.executive.itmedia.co.jp/executive/articles/0808/ 27/news054.html

[33] 大澤幸生:「売る」前に「創る」と「作る」のチャンス発見, 社団法人日本オペレーションズ・リサーチ学会 シンポジ ウム, No.55, pp.23-39, 2006

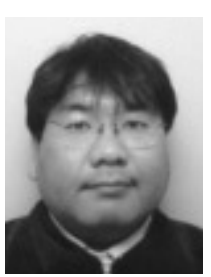

増崎 武次 (学生会員)

1963 年生まれ. 1995 年九州工業大学大学院 工学研究科博士後期課程電気工学専攻退学. 2008 年九州大学大学院芸術工学府博士後期 課程芸術工学専攻退学.

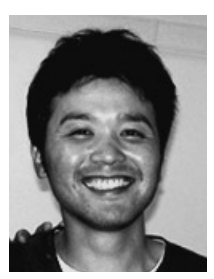

馬場 哲晃 (非会員)

1979年生まれ. 2003 年九州芸術工科大学芸 術情報設計学科卒業. 2005 年同大学大学院 芸術工学専攻博士前期課程修了. 同大学院博 士後期課程を経て, 現在は首都大学東京シス テムデザイン学部インダストリアルアート コース助教. 専門はインタラクティブアートおよびインタラク ションデザイン.

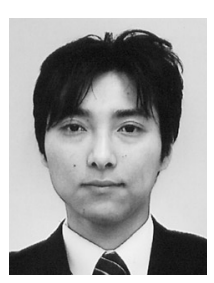

\section{藤木 淳 (非会員)}

2000 年九州芸術工科大学芸術工学部工業設 計学科卒業, 2002年九州芸術工科大学大学 院芸術工学研究科生活環境専攻博士課程前期 修了, 2007 年九州大学大学院芸術工学府芸 術工学専攻博士課程後期修了. 博士 (芸術工

学), 現在, 日本学術振興会特別研究員 PD

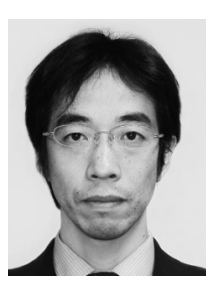

\section{横尾 誠 (非会員)}

2003 年 九州芸術工科大学 芸術工学研究科 生 活環境専攻 博士後期課程修了 博士（芸術 工学), 2003 年より会津大学短期大学部産業 情報学科専任講師, 日本デザイン学会, 芸術 工学会各会員.

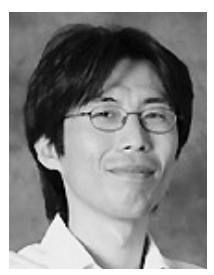

牛尼 剛聡 (非会員)

九州大学大学院芸術工学研究院芸術情報部門 助教. 1996年名古屋大学大学院工学研究科 情報工学専攻博士課程前期課程修了. 1999 年同専攻博士課程後期課程単位取得退学. 博 士 (工学). 個人コンテンッ管理, 実空間コ ンテンツ環境, データベース環境, 実空間インタラクション等 に興味を持つ. 情報処理学会, 電子情報通信学会, IEEE-CS, ACM 会員.

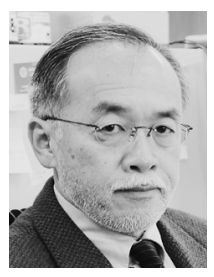

\section{富松 潔 (非会員)}

1953 年福岡県生まれ。九州芸術工科大学卒 業, 英国王立芸術大学院コンピュータリレイ テッドデザインコース修了. 博士（芸術工 学), 三洋電機英国駐在を経て, 1994年九州 芸術工科大学講師, 現在は九州大学大学院教 授, 所属は芸術工学府デザインストラテジー専攻, 専門はイン タラクションデザイン。 日本セーリング連盟アンパイア. 